\title{
Pengaruh Kompetensi Sumberdaya Manusia guna Meningkatkan Sistem Pengendalian Internal Pasien Rumah Sakit Era Covid-19
}

\author{
Lesi Hertati ${ }^{\bowtie}$, Rilla Gantino ${ }^{2}$, Lilis Puspitawati ${ }^{3}$, Meifida Ilyas ${ }^{4}$, Otniel Safkaur ${ }^{5}$. \\ 1Department of Accounting, Indo Global Mandiri University Palembang-Indonesia \\ 2Department of Accounting, Esa Unggul University Jakarta-Indonesia \\ 3Department of Accounting, Komputer Indonesia University Bandug-Indonesia \\ ${ }^{4}$ Department of Accounting, Satya Negara Indonesia University Jakarta-Indonesia \\ 5Departement of Accounting, Universitas Cendrawasih Papua- Indonesia \\ DOI : https://doi.org/10.37531/ecotal.v2i2.29
}

\begin{abstract}
ABSTRAK
Populasi dalam penelitian ini adalah 250 pasien rumah sakit pada daerah Skouw Mabo, Skouw, Yambe, Skouw Sae, dan Mosso Distrik Muara Tami, Kota Jayapura. Keempat daerah ini adalah daerah perbatasan Republik Indonesia dan Papua New Guinea. Metode pengumpulan sampel adalah purposive sampling dengan mengambil sampel pada pasien rumah sakit. Penelitian ini menggunakan metode analisis PLS (Partial Least Square). Penelitian ini menggunakan data primer berupa kuesioner dan dibagikan kepada 300 (tiga ratus) orang responden yang merupakan pasien rumah sakit, jumlah pasien yang mengembalikan sampel ada 250 pasien. Hasil penelitian menunjukkan bahwa kompetensi sumberdaya manusia guna meningkatkan sistem pengendalian internal pasien rumah sakit era covid-19. Hal ini menunjukkan bahwa sumber daya manusia menjadi hal yang penting dan harus diperhatikan dalam menangani pasien rumah sakit era Covid19. Semakin kompoten sumberdaya manusia maka akan semakin baik sistem pengendalian internal pasien rumah sakit era Covid-19.
\end{abstract}

\section{Kata Kunci :}

Kompetensi Sumberdaya Manusia, Sistem Pengendalian Internal.

Abstrak : The population in this study were 250 hospital patients in the areas of Skouw Mabo, Skouw, Yambe, Skouw Sae, and Mosso, Muara Tami District, Jayapura City. These four areas are the border areas of the Republic of Indonesia and Papua New Guinea. The sample collection method is purposive sampling by taking samples from hospital patients. This study uses the PLS (Partial Least Square) analysis method. This study used primary data in the form of a questionnaire and distributed to 300 (three hundred) respondents who were hospital patients, the number of patients who returned the sample was 250 patients. The results showed that the competence of human resources was to improve the internal control system for hospital patients in the Covid-19 era. This shows that human resources are important and must be considered in dealing with Covid-19 era hospital patients. The more competent human resources are, the better the internal control system for hospital patients in the Era Covid-19. Keywords : Human Resource Competence, Internal Control System

$\triangle$ Corresponding Author:

E-mail address: hertatilesi@yahoo.co.id (Kec. Sukarame, Kota Palembang, Indonesia)

“Received 18 Februari 2021, Accepted 16 Maret 2021, Published 20 Juni 2021" 
Lesi Hertati ${ }^{\bowtie}$, Rilla Gantino ${ }^{2}$, Lilis Puspitawati ${ }^{3}$, Meifida Ilyas ${ }^{4}$, Otniel Safkaur $^{5}$.

Pengaruh Kompetensi Sumberdaya Manusia guna Meningkatkan Sistem Pengendalian Internal

DOI : $\underline{\text { https://doi.org/10.37531/ecotal.v2i2.29 }}$

\section{Pendahuluan}

Virus SARS-Covid-19 menyebar di antara orang-orang terutama melalui percikan pernapasan (droplet) yang dihasilkan dari batuk. Percikan ini juga dapat dihasilkan dari bersin dan pernapasan normal. virus dapat menyebar akibat menyentuh permukaan benda yang terkontaminasi dan kemudian menyentuh wajah seseorang. Covid-19 menular saat orang yang menderitanya memiliki gejala, penyebaran terjadi gejala muncul. Paparan virus dan munculnya gejala biasanya sekitar lima hari, tetapi dapat berkisar dari dua hingga empat belas hari. Umumnya gejala di antaranya demam, batuk, dan sesak napas. Komplikasi dapat berupa pneumonia dan penyakit pernapasan akut berat. Pengobatan primer yang diberikan berupa terapi simtomatik dan suportif. Langkah-langkah pencegahan yang direkomendasikan di antaranya mencuci tangan, menutup mulut saat batuk, menjaga jarak dari orang lain, serta pemantauan dan isolasi diri untuk orang yang mencurigai bahwa mereka terinfeksi. (Aruga, Islam, 2020: Auler, assaro, 2020: Adams, 2020: Hertati, et,all, 2020: De Benito, 2020: De Benito, 2020: Collivignarelli,,et,all, 2020: Hertati, Zarkasy, Adam, Umar, Suharman, 2020).

Upaya untuk mencegah penyebaran virus corona termasuk pembatasan perjalanan, karantina, pemberlakuan jam malam, penundaan dan pembatalan acara, serta penutupan fasilitas. Upaya ini termasuk karantina Hubei, karantina nasional di Italia dan di tempat lain di Eropa. penapisan di bandara dan stasiun kereta, serta informasi perjalanan mengenai daerah dengan transmisi lokal. Sekolah dan universitas telah ditutup baik secara nasional atau lokal di lebih dari 124 negara dan memengaruhi lebih dari 1,2 miliar siswa.

Pandemi menyebabkan gangguan sosioekonomi global, penundaan atau pembatalan acara olahraga dan budaya dan kekhawatiran luas tentang kekurangan persediaan barang yang mendorong Seiring dengan perkembangan perkembangan teknologi di Indonesia mendorong berkembangnya rumah sakit yang lebih baik sehingga rumah sakit yang ada akan berkembang menjadi rumah sakit besar. Berkembangnya rumah sakit maka ruang lingkup operasi rumah sakit akan bertambah besar dan permasalah yang akan dihadapi akan semakin kompleks, sehingga kemampuan direktur dalam mengendalikan rumah sakit semakin terbatas. (Broomandi, Karaca, 2020: Casado, Aranda, 2020: Chahrour, Assi, Bejjani, 2020: Debgupta, 2020). 
Lesi Hertati ${ }^{\bowtie}$, Rilla Gantino², Lilis Puspitawati³, Meifida Ilyas ${ }^{4}$, Otniel Safkaur ${ }^{5}$.

Rumah Sakit merupakan suatu organisasi yang bergerak dibidang pelayanan kesehatan yang sehari-hari melakukan kontak dengan pasien. Oleh karena itu, sebuah rumah sakit harus mampu memenuhi kebutuhan yang diperlukan oleh pasien sehingga dapat meningkatkan derajat kesehatan yang setinggi-tingginya. Untuk meningkatkan derajat kesehatan yang setinggitingginya sangat diperlukan berbagai fasilitas yang memadai dalam rumah sakit tersebut. Konsekuensi dari adanya keterbatasan tersebut, maka direktur rumah sakit merasa perlu untuk mendelegasikan wewenang kepada bawahannya walaupun wewenang dapat dilimpahkan kepada bawahan namun tanggung jawab tetap ada pada Direktur, fungsi pengawasan dalam meningkatkan efektifitas kerja pegawai dalam setiap bagian yang ada di rumah sakit perlu dilakukan oleh setiap rumah sakit dimanapun. Hal ini guna menghindari hal-hal yang kurang menguntungkan bagi rumah sakit. (Aditama, 2008: Banerjee, Baker, 2020: Hertati, et,all, 2020).

Sumber daya manusia merupakan salah satu faktor yang menentukan keberhasilan atau kegagalan suatu rumah sakit. Semua orang yang menduduki jabatan manejerial atau pejabat negara sekalipun merupakan sumber daya manusia. Sistem pengendalian internal merupakan sebagai suatu proses untuk menentukan pekerjaan apa yang sudah dilaksanakan, menilainya dan juga suatu mengoneksi dengan maksud supaya pelaksanaan pekerjaan sesuai dengan rencana semula. Efektifitas kerja pegawai dapat diukur dengan menilai hasil yang dicapai, tingkah laku yang ditampilkan berdasarkan dengan tugasnya. Efektifitas kerja dimulai dari tingkat pencapaian target, nisiatif, inspirasi dan kerjasama yang baik dalam kelompok dengan kesadaran akan pengembangan diri untuk meningkatkan kompetensi sumberdaya manusia yang baik. Faktor lain yang dapat mendukung keberhasilan kerja pegawai adalah seorang pemimpin yang bisa memberikan dorongan, nilai, dan motivasi kepada pegawai untuk bekerja dengan baik dibawah pengawasannya. Pemimpin dapat mengancam untuk memberikan hukuman kapada pegawai yang tidak bekerja dengan baik. apabila pemimpin sudah memberikan dorongan atau motivasi kepada pegawai tentulah kepuasan kerja dan kinerja pegawai akan mudah, bahkan bisa berakibat buruk bagi pegawai yang bersangkutan. (Briz-Red', Serrano-Aroca, 2020: Churchill Medical Directory, 2008: Casanova, Jeon, 2010: Syafarudin \& Hertati, 2020: Siagian, 2008: García Charton, 2020: Gallego \& Font,2020: Felice \& Polimeni,2020: Depkes,2020).

Bagi pegawai, kompetensi sumberdaya manusia yang andal sangat berguna untuk mencapai kinerja, karena kompetensi sumberdaya manusia sangat penting dalam rangka mencapai tujuan 


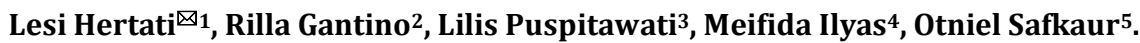

perusahaan yang telah ditentukan. Suatu rumah sakit yang ingin berhasil dalam mencapai sasarannya harus mampu menentukan pegawai/karyawan yang tepat untuk suatu jabatan atau pekerjaan. Sebuah pekerjaan merupakan gambaran dari pencerminan tugas kewajibankewajiban dan tanggung jawab dari setiap pegawai/karyawan terhadap pekerjaannya. Peranan sistem pengendalian internal dalam meningkatan efektifitas kerja pegawai harus dilakukan oleh setiap rumah sakit dimanapun. Sistem pengendalian internal rumah sakit Era covid-19 cukup berperan dalam mengatasi mewabahnya pasien sakit akibat Covid-19 dimana aktivitas selamanya adalah memberikan pelayanan kepada pasien yang membutuhkan perawatan baik dirawat inap maupun dirawat jalan. Seperti sebagian besar rumah sakit lain maka rumah sakit ini juga bertujuan untuk mendapatkan keuntungan yang optimal. Dalam menjalani kegiatan operasionalnya rumah sakit melakukan sistem pengendalian internal dalam meningkatkan efektifitas kerja pegawai. Maka pemimpin rumah sakit harus mempertimbangkan faktor-faktor yang dapat meningkatkan kinerja pegawai serta manajemen pengembangan sumber daya manusia seperti sistem pengawasan yang ketat dan pengembangan.( Radanliev, Roure, 2020: Prata \& Rodrigues, 2020: Pirouz \& Shaffiee, 2020).

Sistem pengendalian internal dalam meningkatkan efektifitas kerja pegawai pada bagian tersebut, karena dengan adanya sistem pengendalian internal, pasien merasa bahwa mereka mendapat perhatian dan pelayanan prima dari pihak rumah sakit, sehingga mendorong para pegawai di bagian rumah sakit untuk menunjukan kinerja yang baik. Para medis bekerja dengan mempedomani aturan pekerjaan yang telah ditetapkan oleh rumah sakit. Kinerja yang baik ditunjukan dokter-dokter yang merupakan hal yang sangat penting dalam upaya pencapaian tujuan rumah sakit. Peranan sistem pengendalian internal dalam meningkatkan efektifitas kerja para medis, merupakan indikator untuk mencapai kinerja rumah sakit. Pentingnya sistem pengendalian internal terhadap pegawai pada bagian pelayanan kesehatan bertujuan untuk mengetahui perkembangan pegawai sehingga membantu pihak rumah sakit pasien pelayan kesehatan pasien bisa terpenuhi. Perjuangan melawan COVID-19 sejak Januari 2020 telah menjadi prioritas utama lebih dari 200 negara. (Kleinschroth \& Kowarik, 2020: Klenert \& Funke, 2020: Karuppasamy \& Seshachalam, 2020).

Analisis bibliometrik dari perspektif disiplin ilmu seperti biologi, kedokteran, sosioekonomi dan pariwisata guna mempersempit penyebaran Covid-19 antar orang perorang.. Namun belum ada 
Lesi Hertati ${ }^{\bowtie}$, Rilla Gantino², Lilis Puspitawati³, Meifida Ilyas ${ }^{4}$, Otniel Safkaur ${ }^{5}$.

analisis bibliometrik yang menyelidiki penyebaran COVID-19 yang menyebar penurunan lewat tajam polusi udara dan peningkatan tingkat polusi air; (ii) hubungan angin kecepatan (positif), radiasi ultraviolet (positif) dan kelembaban (negatif) dengan laju infeksi; (iii) efek pandemi pada rantai pasokan makanan dan kebiasaan membuang sampah; (iv) menawarkan pemantauan air limbah yang bagus berpotensi sebagai tanda peringatan dini penularan COVID-19; (v) kecerdasan buatan dan perangkat pintar dapat sangat berguna dalam memantau mobilisasi warga; dan (vi) pelajaran yang diperoleh dari pandemi yang membantu menentukan tindakan untuk mengurangi perubahan iklim. Agar masa mendatang yang merupakan titik awal bagi para akademisi di bidang kajian lingkungan untuk mengevaluasi dampaknya COVID-19. (Ma, Yueling, et al, 2020: Li, Song, Wong, 2020: Lawley, 2020: La Rosa, et,all, 2020: Keulertz \& Mulligan, 2020).

Meskipun langkah positif sedang dibuat dalam studi keterkaitan antara COVID-19 dan lingkungan, temuan analisis saat ini menawarkan jaringan tematik yang menawarkan arah untuk masa depan garis penelitian. Pertama, pekerjaan di masa depan harus menyelidiki dampak dari kualitas air pada penyebaran dan pengendalian COVID-19. Kedua, meskipun bukti yang jelas tentang dampak faktor meteorologi pada COVID-19 kematian dan penularan, lingkungan yang tidak bersahabat untuk rentang suhu yang mendukung penyebaran COVID-19. Studi prospektif sekarang dalam posisi yang baik untuk mengevaluasi hubungan ini di zona tropis yang berbeda. Ketiga, eksplorasi studi masa depan perubahan sosial dalam konsumsi energi, pembelian lingkungan nyata, perilaku menyia-nyiakan dan kegiatan santai diperlukan untuk memajukan pemahaman dari efek pandemi pada rutinitas sosial sehari-hari. Keempat, meskipun penelitian telah mengidentifikasi penularan melalui udara COVID-19, tidak ada analisis hingga saat ini yang secara khusus menyelidiki sejauh mana faktor meteorologi atau konteks perkotaan mempengaruhi jenis transmisi ini. Terakhir, lebih banyak studi lingkungan diperlukan untuk menilai cara masuknya perangkat pintar dan platform pemantauan mana yang dapat membantu pencegahan dan pencegahan penyebaran COVID-19. (Mlejnkova, \& Sovova, 2020: Morawska \& Cao, 2020: Meles \& Ryan, 2020: Ma \& Kang, 2020: An’onimo, 2020).

\section{Kajian Literatur}

\subsection{Kompetensi Sumberdaya Manusia}

Sumber daya manusia merupakan salah satu sumber daya yang terjadi didalam organisasi, meliputi semua orang yang melakukan kegiatan atau aktivitas. Secara universal, sumber daya 


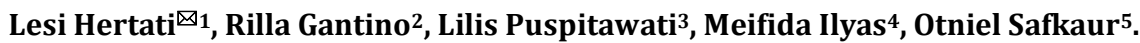

Pengaruh Kompetensi Sumberdaya Manusia guna Meningkatkan Sistem Pengendalian Internal

DOI : $\underline{\text { https://doi.org/10.37531/ecotal.v2i2.29 }}$

manusia yang terdapat dalam suatu organisasi dikelompokkan menjadi dua macam yaitu: (a) Sumber daya manusia (human resource).(b) Sumber daya non manusia (non human resource). Pengertian manajemen menurut Simamora (2011) adalah proses pendayagunaan bahan baku dan sumber daya manusia untuk mencapai tujuan yang ditetapkan. Proses ini melibatkan organisasi arahan, koordinasi, dan evaluasi orang-orang yang mencapai berbagai hasil. Esensi manajemen adalah aktivitas bekerja dengan orang lain agar mencapai berbagai hasil. Melalui manajemen dilakukan proses pengintegrasian berbagai sumber dan tugas untuk mencapai berbagai tujuan organisasi yang telah ditentukan. Simamora (2011) menyatakan bahwa manajemen sumber daya manusia adalah pendayagunaan, pengembangan, penilaian, pemberian balas jasa dan pengelolaan individu anggota organisasi atau kelompok pekerja. (Hertati,Zarkasyi.Suharman.Umar, 2019: Haryanto, 2010: Hasibuan,\& Malayu, 2008: Gupta,et,all, 2020: Hertati., 2015: Goffman, 2020: Ghazaly,et,all, 2020).

Handoko (2010), mengtakan bahwa manajemen sumber daya manusia adalah manajemen sumber daya manusia adalah penarikan, seleksi, pengembangan, pemeliharaan dan penggunaan sumber daya manusia untuk mencapai baik tujuan-tujuan individu maupun organisasi. Kompetensi sumber daya manusia menurut Heidjrachman \& Husnan (2010) adalah perencanaan, pengorganisasian, pengarahan dan pengawasan dari pengadaan, pengembangan, pemberian kompensasi, pengintegrasian dan pemeliharaan tenaga kerja dan maksud untuk membantu mencapai tujuan perusahaan, individu dan masyarakat. Manajemen sumber daya manusia merupakan pemanfatan sumber daya manusia agar mencapai tujuan organisasional, konsekuensinya manajer-manajer pada semua jajaran menaruh perhatian pada sumber daya manusia. Pada hakekatnya manajer-manajer membuat segala sesuatu dilakukan melalui upaya orang-orang lain yang membutuhkan pengelolaan sumber daya manusia yang efektif. Manajemen sumber daya manusia yang baik mengharuskan anggota organisasi untuk mencapai tujuan.( Aminarti\& Novi, 2007: Bonilla-Aldana, 2020: Centers for Disease Control \& Prevention, 2020: Chakraborty,et,all, 2020: Chan,et,all, 2011: Choi, Lee, Jamal,2020: Cobo, et,all,2011: Henriques, 2020: Gundy \& Gerba,2008: Gray, 2020).

Para manajer harus mencapai kiat meningkatkan kepuasan karyawan, keterlibatannya dalam kehidupan organisasi, memperbaiki kualitas lingkungan kerja dan efisiensi produktivitas karyawan. manajemen sumber daya manusia yang efektif dapat meningkatkan efektivitas 
Lesi Hertati ${ }^{\bowtie}$, Rilla Gantino², Lilis Puspitawati³, Meifida Ilyas ${ }^{4}$, Otniel Safkaur ${ }^{5}$.

Pengaruh Kompetensi Sumberdaya Manusia guna Meningkatkan Sistem Pengendalian Internal

DOI : $\underline{\text { https://doi.org/10.37531/ecotal.v2i2.29 }}$

perusahaan. Manajemen sumber daya manusia adalah mengelola atau mengurus sumber daya manusia. Dari keseluruhan dari sumber daya yang tersedia dalam suatu organisasi, baik organisasi publik maupun swasta, sumber daya manusialah yang paling penting dan sangat menentukan. Karena sumber daya manusia memiliki ratio, rasa, dan karsa. Kemudian sumber daya manusia merupakan satu-satunya sumber yang memiliki akal, perasaan, keinginan, kemampuan, ketrampilan, pengetahuan, dorongan daya dan karsa. Semua potensi sumber daya manusia tersebut sangat berpengaruh terhadap upaya organisasi dalam mencapai tujuannya. Betapa besar majunya teknologi, berkembangnya informasi tersedianya modal dan memadainya bahan (material), namun jika tanpa sumber daya manusia maka akan sulit bagi organisasi untuk mencapai tujuannya. (Cobo,et,all, 2012: Cole, Ozgen, 2020: Comunian, S., Dongo, 2020: Hertati, Syafarudin, Safkaur. Fery. 2020).

Manajemen sumber daya manusia mencakup masalah-masalah yang berkaitan dengan pembinaan, penggunaan, dan perlindungan sumber daya manusia. Manajemen sumber daya manusia yang vital bagi pencapaian tujuan-tujuan organisasi, dan pemanfaatan berbagai fungsi dan kegiatan personalia untuk menjamin bahwa mereka digunakan secara efektif dan bijak agar bermanfaat bagi individu, organisasi, dan masyarakat. Penggantian istilah manajemen personalia dengan manajemen sumber daya manusia dianggap sebagai suatu gerakan yang mencerminkan pengakuan adanya peran vital dan semakin pentingnya sumber daya manusia dalam suatu organisasi, adanya tantangan-tantangan yang semakin besar dalam pengelolaan sumber sumber daya manusia efektif, serta terjadinya pertumbuhan ilmu pengetahuan dan profesionalisme di bidang manajemen sumber daya manusia. (Husein, 2007: Hossain, 2020.: Iqbal \& Fareed, 2020: Inversini \& Boes,2016: Lin, \& Huang, 2020: Martoyo, 2008: Notoatmojo, 2009).

\subsection{Sistem Pengendalian Internal Pasien Rumah Sakit Era Covid-19}

Manullang (2008), Sistem Pengendalian Internal merupakan sebagai suatu proses untuk menerapkan pekerjaan apa yang sudah dilaksanakan, menilainya, dan bila perlu mengoreksi dengan maksud supaya pelaksanaan pekerjaan sesuai dengan rencana semula. Negara (2008), mengemukakan, Sistem Pengendalian Internal adalah ketepatan dalam menguji apapun suatu persetujuan yang disesuaikan dengan instruksi dan prinsip perencanaan yang sudah tidak dapat dipungkiri lagi. Beishline dalam Manullang (2008), Sistem Pengendalian Internal dapat dibedakan atas kontrol administratif dan kontrol operatif. Kontrol operatif untuk bagian terbesar berurusan

Volume 2 Issue 2 (2021)

Economics and Digital Business Review

ISSN: 2774-2563 (Online) 
Lesi Hertati ${ }^{\bowtie}$, Rilla Gantino², Lilis Puspitawati³, Meifida Ilyas ${ }^{4}$, Otniel Safkaur ${ }^{5}$.

dengan tindakan, kontrol administratif berurusan dengan tindakan dan pikiran. Agar aktivitas produksi dapat berjalan sesuai dengan rencana yang telah ditetapan, maka manajer atau pimpinan perusahaan perluh membuat suatu mekanisme pengawasan agar sesuai dengan standar yang ditetapkan. Ada berbagai ciri-ciri yang membuat Sistem Pengendalian Internal semakin diperlukan oleh setiap organisasi (Negara 2001: Lin, et,all, 2020: Manullang, 2008: Mukanjari,, Sterner, 2020), yaitu :

\section{Perubahan Lingkungan Organisasi}

Berbagai perubahan lingkungan organisasi terjadi terus menerus dan tak dapat dihindari lagi, melalui fungsi pengawasan manajer mendekteksi perubahan-perubahan yang berpengaruhi, sehingga bersaing atau menghadapi tantangan atau memanfaatkan kesempatan yang diciptakan perubahan-perubahan yang terjadi.

\section{Menciptakan Kompleksitas Organisasi}

Semakin besar organisasi semakin memerlukan pengawasan yang lebih formal dan hati-hati untuk menjamin bahwa kualitas dan profitabilitas tetap terjaga, misalnya penjualan pada penyalur perluh dianalisis dan dicatat secara sistematis Dan dimonitor perkembangannya.

\section{Kesalahan-kesalahan}

Bila para bawahan tidak pernah membuat kesalahan manajer dapat secara sederhana melakukan fungsi pengawasan. Tetapi kebanyakan bawahan sering membuat kesalahan sehingga kesalahankesalahan tersebut perlu dianalisis dan memungkinkan manajer mendekteksi kesalahankesalahan tersebut sebelum menjadi kritis.

\section{Kebutuhan manajer untuk mendelegasikan mewenang}

Bila manajer mendelegasikan wewenang kepada bawahan, tanggung jawab manajer tidak berkurang satu-satunya cara manajer dapat menentukan apakah bawahan telah melakukan tugas-tugas yang telah dilimpahkan pada bawahannya adalah dengan mengimplementasikan sistem pengawasan dan tanpa sistim tersebut manajer tidak dapat memeriksa bawahannya.

Setiap personil perusahaan dituntut agar dapat bekerja efektif, efisien, kualitas dan kuantitas pekerjaannya baik sehingga daya saing perusahaan semagkin besar. Pengembangan ini dilakukan 
Lesi Hertati ${ }^{\bowtie}$, Rilla Gantino², Lilis Puspitawati³, Meifida Ilyas ${ }^{4}$, Otniel Safkaur ${ }^{5}$.

Pengaruh Kompetensi Sumberdaya Manusia guna Meningkatkan Sistem Pengendalian Internal

DOI : $\underline{\text { https://doi.org/10.37531/ecotal.v2i2.29 }}$

untuk tujuan non karier maupun karier bagi para karyawan (baru/lama) melalui latihan dan pendidikan. Sedarmayanti dalam Hasibuan (2008), Pengembangan sumber daya manusia adalah suatu proses peningkatan kualitas untuk mencapai tujuan pembangunan bangsa. Salah satu upaya pengembangan sumber daya manusia adalah melalui pendidikan dan pelatihan. Haryanto (2010), Kompetensi sumberdaya manusia didalam suatu organisasi adalah suatu proses pengembangan kemampuan kearah yang diinginkan oleh organisasi yang bersangkutan dan pendidikan pegawai adalah kegiatan pengembangan sumber daya manusia untuk meningkatkan tata dari pegawai diluar kemampuan dibidang pekerjaan atau jabatan yang dipegang saat ini. Martoyo (2008), Kompetensi sumberdaya manusia pada dasarnya adalah suatu proses pengembangan sumber daya manusia. pengertian pendidikan disini dapat dikatakan bahwa pendidikan sama dengan pengembangan sumber daya manusia. Notoatmojo (2009). Pelatihan atau training merupakan bagian dari suatu proses pendidikan, yang tujuannya untuk meningkatkan kemampuan atau kemampuan khusus seseorang atau kelompok orang, Martoyo (2008), Kompetensi sumberdaya manusia adalah memperbaiki penguasaan berbagai keterampilan dan teknik pelaksanaan kerja tertentu dalam waktu yang relatif singkat (pendek), umumnya suatu latihan berupaya menyiapkan para karyawan untuk melakukan pekerjaan-pekerjaan. (Negara, 2001: Nabi \& Siddique, 2020: Nadikattu \& Mohammad,2020).

Pelaksanaan sistem pengendalian internal pada Rumah Sakit Umum Papua seperti : waktu pengawasan dilakukan secara refressif yaitu pengawasan dilaksanakan setelah rencana sudah berjalan, dengan kata lain diukur hasil-hasil yang dicapi sesuai tujuan organisasi. Tujuannya untuk menentukan, apakah dalam meghasilkan sesuatu sesuai dengan waktu yang direncanakan atau tidak. Subjek pengawasan dilakukan secara sistem pengendalian intern yaitu pengawasan dilakukan oleh atasan dari petugas yang bersangkutan. Faktor lain yang dapat mendukung untuk keberhasilan kerja dokter dan para medis perluh dilakukan oleh seorang kepala rumah sakit adalah memberikan dorongan atau motivasi kepada bidan untuk bekerja dengan baik dibawah pengawasannya. Pemimpin dapat mengancam untuk memberikan hukuman kepada setiap bidan yang tidak bekerja dengan baik. Apabila pemimpin tidak memberikan dorongan atau motivasi kepada bidan tentulah kepuasan kerja dan kinerja bidan akan rendah, bahkan bias berakibat buruk bagi bidan yang bersangkutan. Bagi dokter dan para medis motivasi sangat berguna untuk mencapai kinerja dokter dan para medis karena motivasi penting dalam ra ngka mencapai tujuan 
Lesi Hertati ${ }^{\bowtie}$, Rilla Gantino², Lilis Puspitawati ${ }^{3}$, Meifida Ilyas ${ }^{4}$, Otniel Safkaur ${ }^{5}$

Pengaruh Kompetensi Sumberdaya Manusia guna Meningkatkan Sistem Pengendalian Internal

DOI : $\underline{\text { https://doi.org/10.37531/ecotal.v2i2.29 }}$

perusahaan yang telah ditentukan. (Jumba, F.R., Tibasiima, 2020: Howarth \& Bryant, 2020: Howarth, et,all, 2020)

Rumah Sakit Umum Papua telah melakukan sistem pengendalian internal dalam meningkatkan efektifitas kerja bidan di Rumah Sakit Umum Papua, dimana pelaksanaan sistem pengawasan pelayanan yang diterapkan yaitu dengan adanya pengawas, tanggung jawab dan wewenang pengawas terhadap kegiatan pelayanan kebidanan di Rumah Sakit Umum Papua. Rumah Sakit Umum Papua menerapkan sistem sistem pengendalian internal dalam meningkatkan efektifitas kerja dokter dan para medis di Rumah Sakit Umum Papua yaitu dapat meningktkan kedisiplinan bidan. Mengefektifkan pengadaan bidan, menciptakan suasana dan hubungan kerja yang baik, meningkatkan loyalitas, kreativitas, dan partisipasi bidan, meningkatkan tingkat kesejahteraan bidan, mempertinggi rasa tanggung jawab bidan terhadap tugas-tugasnya dan meningkatan efesiensi penggunaan alat-alat dan bahan baku.

Hipotesis : penenlitian ini bagaimana pengaruh Kompetensi Sumberdaya Manusia berpengaruh terhadap Sistem Pengendalian Internal.

Gambar 1. Kerangka Konseptual Penelitian, 2020

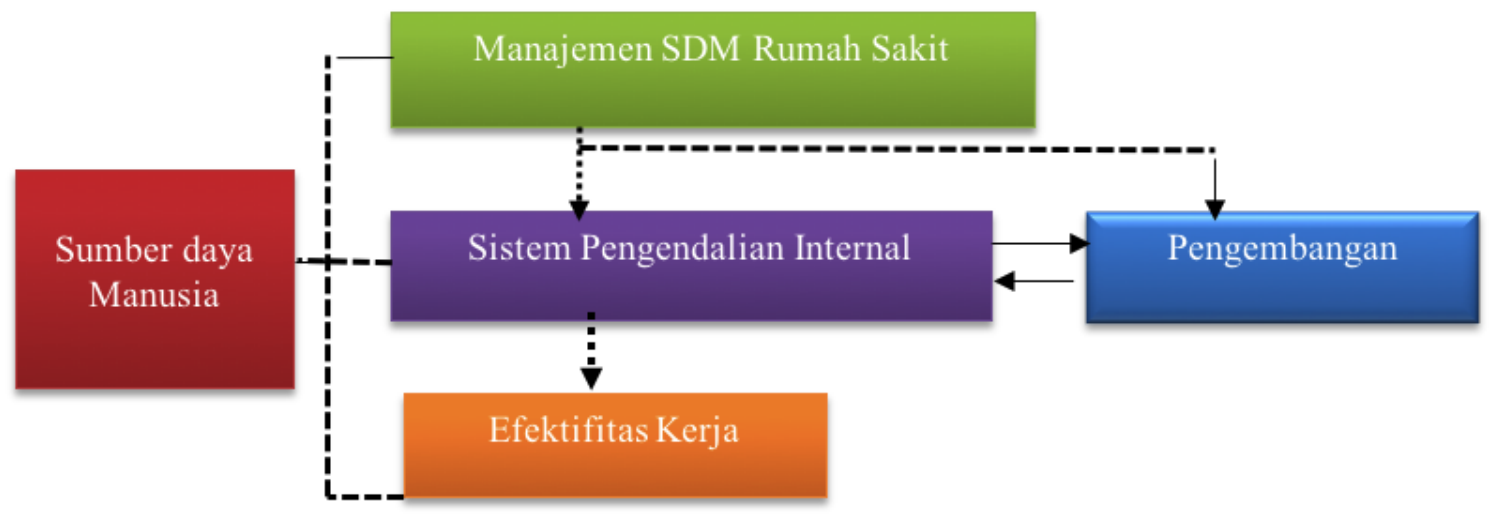

\section{Hasil Penelitian dan Pembahasan}

Metode pengambilan sampel dalam penelitian ini menggunakan accidental sampling. Accidental sampling adalah teknik penentuan sampel berdasarkan kebetulan, yaitu siapa saja yang secara kebetulan bertemu dengan peneliti dapat digunakan sebagai sampel bila dipandang orang tersebut cocok sebagai sumber data. Penentuan ukuran sampel menggunakan pendekatan Taro Yamane. Penentuan ukuran sampel dalam penelitian ini menggunakan rumus Taro Yamane (Hair, etall, 2014) sebagai berikut. 
Lesi Hertati ${ }^{\bowtie}$, Rilla Gantino ${ }^{2}$, Lilis Puspitawati³ ${ }^{\text {, Meifida Ilyas }}{ }^{4}$, Otniel Safkaur5.

$n=\frac{N}{N \cdot d^{2}+1}$

Di mana:

$\mathrm{n} \quad=$ Sampel

$\mathrm{N}=$ Jumlah populasi

$d^{2}=$ Presisi (ditetapkan 5\%)

Berdasarkan jumlah populasi yang berjumlah 300 pasien rumah sakit dengan e yang digunakan adalah 5\%. Berdasarkan perhitungan diperoleh jumlah sampel minimal 300. Menurut Hair et al (2014), bahwa di dalam model persamaan struktural (SEM) ukuran sampel memainkan peran penting dalam estimasi dan interpretasi hasil-hasil SEM, maka direkomendasikan ukuran sampel antara 100 hingga 200. Dengan demikian, jumlah sampel dalam penelitian telah memenuhi syarat sampel minimal dalam SEM. Untuk menentukan responden sebagai sampel dengan cara menemui dan menyebarkan kuesioner kepada pasien berobat pada rumah sakit akibat Covid-19. Hair, et,all, 2014) menyatakan bahwa uji validitas dilakukan yang digunakan untuk menentukan kelayakan item dalam daftar pertanyaan untuk menentukan variabel dan uji reliabilitas untuk mengukur keandalan objek yang diukur. Pada uji validitas ini, digunakan korelasi Product Moment Pearson. Cara pengukurannya yaitu dengan menghitung korelasi antara skor masing-masing item pertanyaan pada kuisioner dengan skor total kuisioner. Jika nilai $r$ hitung $>r$ tabel dan atau nilai sig $<0.05$, maka item pertanyaan tersebut dianggap valid. Berdasarkan perhitungan persentase skor jawaban responden diperoleh hasil seperti tampak dalam tabel berikut ini:

Tabel 1. Nilai Loading factor

\begin{tabular}{|c|c|c|c|c|}
\hline \multirow{2}{*}{$\begin{array}{l}\text { Indikator } \\
\text { Kompetensi } \\
\text { Manusia }\end{array}$} & \multicolumn{3}{|c|}{ Indikator } & \multirow[t]{2}{*}{ Outer Loading } \\
\hline & Sumberdaya & $\begin{array}{l}\text { Sistem } \\
\text { Internal }\end{array}$ & Pengendalian & \\
\hline KSM 1 & & SPI 1 & & 0.775 \\
\hline KSM 2 & & SPI 2 & & 0.862 \\
\hline KSM 3 & & SPI 3 & & 0.826 \\
\hline KSM 4 & & SPI 4 & & 0.829 \\
\hline KSM 5 & & SPI 5 & & 0.778 \\
\hline KSM 6 & & SPI 6 & & 0.665 \\
\hline KSM 7 & & SPI 7 & & 0.831 \\
\hline KSM 8 & & SPI 8 & & 0.810 \\
\hline KSM 9 & & SPI 9 & & 0.764 \\
\hline KSM 10 & & SPI 10 & & 0.756 \\
\hline KSM 11 & & SPI 11 & & 0.831 \\
\hline KSM 12 & & SPI 12 & & 0.831 \\
\hline KSM 13 & & SPI 1 & & 0.831 \\
\hline KSM 14 & & SPI 2 & & 0.831 \\
\hline
\end{tabular}


Lesi Hertati ${ }^{\bowtie}$, Rilla Gantino², Lilis Puspitawati ${ }^{3}$, Meifida Ilyas ${ }^{4}$, Otniel Safkaur ${ }^{5}$.

Pengaruh Kompetensi Sumberdaya Manusia guna Meningkatkan Sistem Pengendalian Internal

DOI : https://doi.org/10.37531/ecotal.v2i2.29

\begin{tabular}{lcc} 
KSM 15 & - & 0.831 \\
\hline KSM 16 & - & 0.831 \\
\hline KSM 17 & - & 0.831 \\
\hline KSM 18 & - & 0.831
\end{tabular}

Sumber: Hasil Uji Loading Factor, 2020

Tabel 2. Nilai Average Variance Extracted (AVE)

\begin{tabular}{ll}
\hline Variabel & AVE \\
\hline Kompetensi Sumberdaya Manusia & 0.562 \\
\hline Sistem Pengendalian Internal & 0.579 \\
\hline
\end{tabular}

Sumber: Hasil Uji AVE, 2020

Tabel 3. Nilai Composite Reliability

\begin{tabular}{lcll}
\hline Variabel & Composite Reliability & Cronbach Alpha \\
\hline $\begin{array}{l}\text { Kompetensi } \\
\text { Manusia }\end{array}$ & Sumberdaya & $\mathbf{0 . 8 8 4}$ & 0.819 \\
\hline $\begin{array}{l}\text { Sistem Pengendalian Internal } \\
\text { Sum }\end{array}$ & 0.867 & 0.823
\end{tabular}

Sumber: Hasil Uji Composite Reliability, 2020

Tabel 4. Nilai Goodness of fit pada inner model diukur menggunakan R square

\begin{tabular}{llc}
\hline & Nilai R-Square & R-Square Adjusted \\
\hline Kompetensi Sumberdaya Manusia & 0.863 & 0.838 \\
\hline Sistem Pengendalian Internal & 0.652 & 0.635
\end{tabular}

Sumber: Uji Goodness of fit pada inner model diukur menggunakan R square, 2020

Tabel 5. Hasil Uji Q Square

\begin{tabular}{lll}
\hline No & Model & Q square \\
\hline 1. & Nilai Q-Square & 0.940 \\
\hline
\end{tabular}

Sumber: Hasil Uji Q Square, 2020

Tabel 6. Hasil Uji Statistik T

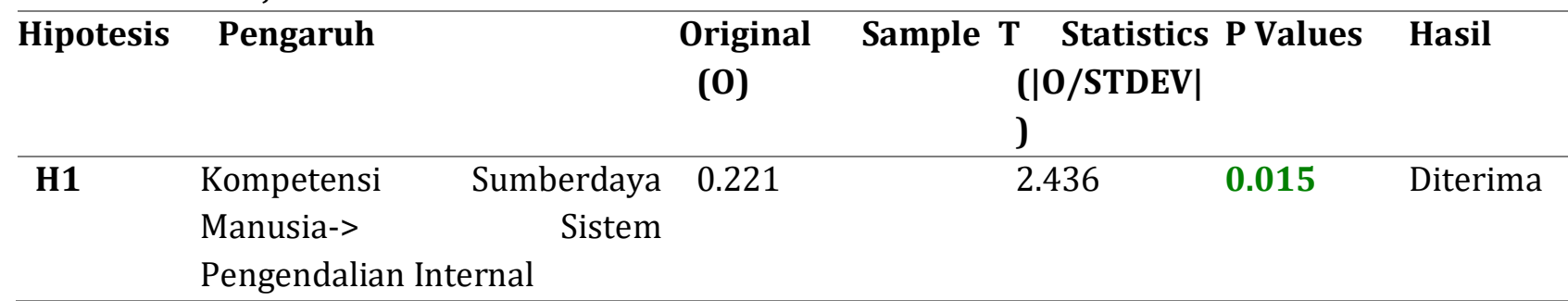

Sumber: Hasil Pengujian Pengaruh, 2020 
Lesi Hertati ${ }^{\bowtie}$, Rilla Gantino², Lilis Puspitawati³, Meifida Ilyas ${ }^{4}$, Otniel Safkaur ${ }^{5}$.

Berdasarkan hasil perhitungan, nampak bahwa tidak ada indikator variabel yang nilai outer loading-nya di bawah 0,5 sehingga semua indikator dinyatakan layak atau valid untuk digunakan penelitian dan dapat digunakan untuk analisis lebih lanjut. Nilai average variant extracted (AVE) untuk masing-masing indikator dipersyaratkan nilainya harus $>0,5$ untuk model yang baik. Composite Reliability merupakan bagian yang digunakan untuk menguji nilai reliabilitas indikator-indikator pada suatu variabel. Suatu variabel dapat dinyatakan memenuhi composite reliability apabila memiliki nilai composite reliability > 0,6 (Imam Ghozali, 2014). Berdasarkan sajian data pada tabel 3 di atas, dapat diketahui bahwa nilai composite reliability semua variabel penelitian $>0,6$. Berdasarkan hasil perhitungan di atas, diperoleh nilai Q-Square sebesar 0,940. Hal ini menunjukkan besarnya keragaman dari data penelitian yang dapat dijelaskan oleh model penelitian adalah sebesar 94,0\% sedangkan sisanya sebesar 6\% dijelaskan oleh faktor lain yang berada di luar model penelitian ini. Dengan demikian, dari hasil tersebut maka model penelitian ini dapat dinyatakan telah memiliki goodness of fit yang baik. Hasil ini menunjukkan bahwa masing-masing variabel telah memenuhi composite realibility sehingga dapat disimpulkan bahwa keseluruhan variabel memiliki tingkat realibilitas yang tinggi. Berdasarkan sajian data pada tabel 7 di atas, dapat diketahui bahwa dari lima hipotesis yang diajukan dalam penelitian ini, semuanya dapat diterima karena masing-masing pengaruh yang ditunjukkan memiliki nilai P-Values $<0,05$ dan nilai statistik $t$ yang lebih besar dari nilai kritis (1.96).

\section{Kesimpulan}

Sistem pengendalian internal pada rumah sakit umum Papua sudah sangat baik dengan adanya pengawas, tanggung jawab dan wewenang pengawas terhadap kegiatan pelayanan dokter dan para medis rumah sakit umum Papua. Pelaksanaan sistem pengawasan pelayanan pada rumah sakit umum Papua guna meningkatkan efektifitas kerja para dokter dan medis yaitu dengan adanya pengawas, tanggung jawab dan wewenang pengawas terhadap kegiatan pelayanan keperawatan di rumah sakit umum Papua. Peningkatkan kedisiplinan para medis mengefektifkan pengadaan para medis menciptakan suasana dan hubungan kerja yang baik, meningkatkan loyalitas, kreativitas, dan partisipasi dokter dan para medis dalam meningkatkan tingkat kesejahteraan dokter dan para medis mempertinggi rasa tanggung jawab dokter dan para medis terhadap tugas-tugasnya dan meningkatkan efesiensi penggunaan alat-alat dan bahan baku dan dokter dan para medis dalam melayani pasien Covid-19 yang bekerja merasa kerjanya diawasi sehingga mereka bekerja dengan efektif. Dalam sistem pengawasan pelayanan pada rumah sakit umum Papua tidak cukup dengan adanya pengawas, tanggung Jawab dan wewenang pengawas terhadap kegiatan pelayanan dokter dan para medis rumah sakit umum Papua, tetapi perluh ditambahkan tupoksi dokter dan para medis yang bersangkutan sesuai dengan jadwal lembur dokter dan para medis tersebut supaya kerja dokter dan para medis dapat efektif. Keefektifan kerja dokter dan para medis dapat teralisasi dengan adanya motivasi atau dorongan dari 
Lesi Hertati ${ }^{凶}$, Rilla Gantino², Lilis Puspitawati³, Meifida Ilyas ${ }^{4}$, Otniel Safkaur5.

pemimpin, ada baiknya rumah sakit umum Papua menerapkan sistem pelayanan dokter dan para medis dengan tupoksi masing-masing dokter dan para medis sesuai dengan jenis pendidikan atau pelatihan yang telah ditempuhnya.

\section{Referensi :}

Adams, M.D., (2020). Air pollution in Ontario, Canada during the COVID-19 state of emergency. Sci. Total Environ.

An'onimo, (2020). Trump reaviva la teoría de que el virus surgi'o en un laboratorio chino. La Raz'on, 16 de abril. Retrieved from. https://www.larazon.es/internacional/202 00416/2gjw7ymfm 5d4lk5p5 zhodsh 3im.html.

Aruga, K., Islam, M.M., Jannat, A., (2020). Effects of COVID-19 on Indian energy consumption. Sustainability 12 (14), 5616. https://doi.org/10.3390/su12145616.

Auler, A.C., C'assaro, F.A.M., da Silva, V.O., Pires, L.F., (2020). Evidence that high temperatures and intermediate relative humidity might favor the spread of COVID- 19 in tropical climate: a case study for the most affected Brazilian cities. Sci. Total Environ. 729, 139090. https://doi.org/10.1016/j.scitotenv.2020.139090.

Aditama (2008). Manajemen Administrasi Rumah Sakit. Edisi Ke dua. Jakarta : Universitas Indonesia.

Aminarti, Novi (2007). Faktor-faktor yang berhubungan dengan Motivasi Kerja Pengawai Rumah Sakit dan Bersalin Rika Amelia Palembang.

Banerjee, A., Baker, M., Kulcsar, K., Misra, V., Plowright, R., Mossman, K., (2020). Novel insights into immune systems of bats. Front. Immunol. 11 https://doi.org/10.3389/ fimmu.2020.00026.

Bonilla-Aldana, D.K., Quintero-Rada, K., Montoya-Posada, J.P., Ramírez-Ocampo, S., PanizMondolfi, A., Rabaan, A.A., Sah, R., Rodríguez-Morales, A.J., (2020). SARS-CoV, MERS-CoV and now the 2019-novel CoV: have we investigated enough about coronaviruses? - a bibliometric analysis. Trav. Med. Infect. Dis. 33, 101566. https:// doi.org/10.1016/j.tmaid.2020.101566.

Briz-Red'on, 'A., Serrano-Aroca, 'A., (2020). A spatio-temporal analysis for exploring the effect of temperature on COVID-19 early evolution in Spain. Sci. Total Environ. 728, 138811. https://doi.org/10.1016/j.scitotenv.2020.138811.

Broomandi, P., Karaca, F., Nikfal, A., Jahanbakhshi, A., Tamjidi, M., Kim, J.R., (2020). Impact of COVID-19 event on the air quality in Iran. Aerosol and Air Quality Research 20 (8), 17931804. https://doi.org/10.4209/aaqr.2020.05.0205.

Casado.L.A.Aranda, María JSFI. Jesús.F.d (2020). Analysis of the scientific production of the effect of COVID-19 on the environment: A bibliometric study. Environmental Research journal homepage:

www.elsevier.com/locate/envres. https://doi.org/10.1016/j.envres.2020.110416 1-12

Churchill Medical Directory.(2008). Manajemen Kebidanan, Aplikasi dalam praktek. Penerbit : Jakarta Departemen Kesehatan RI.

Casanova, L.M., Jeon, S., Rutala, W.A., Weber, D.J., Sobsey, M.D., (2010). Effects of air temperature and relative humidity on coronavirus survival on surfaces. Appl. Environ. Microbiol. 76 (9), 2712-2717.

Centers for Disease Control and Prevention, (2020). COVID-19 Research Articles Downloadable Database. Retrieved from. https://www.cdc.gov/library/researchgui des/2019novelcoronavirus/researcharticles. html. 
Lesi Hertati ${ }^{凶}$, Rilla Gantino², Lilis Puspitawati³, Meifida Ilyas ${ }^{4}$, Otniel Safkaur5.

Chahrour, M., Assi, S., Bejjani, M., Nasrallah, A., Salhab, H., Fares, M., Khachfe, (2020). A bibliometric analysis of COVID-19 research activity: a call for increased output. Cureus 12 (3). https://doi.org/10.7759/cureus.7357 e7357.

Chakraborty, P., Jayachandran, S., Padalkar, P., Sitlhou, L., Chakraborty, S., Kar, R., Bhaumik, S., Srivastava, M., (2020). Exposure to nitrogen dioxide (NO2) from vehicular emission could increase the COVID-19 pandemic fatality in India: a perspective. Bull. Environ. Contam. Toxicol. https://doi.org/10.1007/s00128-020- 02937-3, 1-7.

Chan, K.H., Peiris, J.M., Lam, S.Y., Poon, L.L.M., Yuen, K.Y., Seto, W.H., 2011. The effects of temperature and relative humidity on the viability of the SARS coronavirus. Advances in virology 2011. Chang, C.-L., McAleer, M., Ramos, V., (2020). A charter for sustainable $\begin{array}{lllll}\text { tourism after } & \text { COVID-19. } & \text { Sustainability } & 12 & \text { (9), }\end{array}$ https://doi.org/10.3390/su12093671

Choi, J., Lee, S., Jamal, T., (2020). Smart Korea: governance for smart justice during a global pandemic. J. Sustain. Tourism 1-10

Cobo, M.J., L'opez-Herrera, A.G., Herrera-Viedma, E., Herrera, F., (2011). An approach for detecting, quantifying, and visualizing the evolution of a research field: a practical application to the fuzzy sets theory field. Journal of Informetrics 5 (1), 146-166.

Cobo, M.J., L'opez-Herrera, A.G., Herrera-Viedma, E., Herrera, F., (2012). SciMAT: a new science mapping analysis software tool. J. Am. Soc. Inf. Sci. Technol. 63 (8), 1609-1630.

Cole, M.A., Ozgen, C., Strobl, E., (2020). Air pollution exposure and covid-19 in Dutch municipalities. Environ. Resour. Econ. 1-30.

Collivignarelli, M.C., Abb`a, A., Bertanza, G., Pedrazzani, R., Ricciardi, P., Carnevale Miino, M., (2020). Lockdown for CoViD-2019 in Milan: what are the effects on air quality? Sci. Total Environ. 732, 139280.

Comunian, S., Dongo, D., Milani, C., Palestini, P.,(2020). Air pollution and COVID-19: the role of particulate matter in the spread and increase of COVID-19's morbidity and mortality. Int. J. Environ. Res. Publ. Health 17 (12).

Conticini, E., Frediani, B., Caro, D., (2020). Can atmospheric pollution be considered a co-factor in extremely high level of SARS-CoV-2 lethality in Northern Italy? Environ. Pollut. 261, 114465.

De Benito, E., (2020). La agencia del medicamento ha aprobado en un mes 80 ensayos de f'armacos para el COVID-19. El País, 9 de abril. Retrieved from. https://elpais.com/so ciedad/202004-09/la-agencia-del-medicamento-ha-aprobado-en-un-mes-80-ensayo s-de-farmacospara-la-COVID-19.html.

Debgupta, S., (2020). Will the Coronavirus Threaten Our Food? New York Times. March 31st. Retrieved from. https://www.nytimes.com/2020/03/31/opinion/coronaviru s-foodsupply.html.

Dutta, V., Dubey, D., Kumar, S., (2020). Cleaning the River Ganga: impact of lockdown on water quality and future implications on river rejuvenation strategies. Sci. Total Environ. 743, 140756.

Depkes (2020). Pelayanan Kesehatan Masyarakat. Penerbit : Jakarta PT. Rineka Cipta

Felice, F.D., Polimeni, A., 2020. Coronavirus disease (COVID-19): a machine learning bibliometric analysis. In Vivo 34 (3 Suppl. l), 1613-1617.

Gallego, I., Font, X., (2020). Changes in air passenger demand as a result of the COVID-19 crisis: using Big Data to inform tourism policy. J. Sustain. Tourism 1-20.

García Charton, F., 2020. El escenario post-COVID-19, una ventana de oportunidades. Eldiario.es, 21 de abril. Retrieved from. https://www.eldiario.es/murcia/murcia _y_aparte/escenario-post-COVID-19-ventana-oportunidades_6_1018808154.html. 
Lesi Hertati ${ }^{凶}$, Rilla Gantino², Lilis Puspitawati³, Meifida Ilyas ${ }^{4}$, Otniel Safkaur5.

Ghazaly, N., Abdel-Fattah, M., El-Aziz, A., (2020). Novel coronavirus forecasting model using nonlinear autoregressive artificial neural network. International Journal of Advanced Science and Technology 29 (5s), 1831-1849.

Goffman, E., (2020). In the wake of COVID-19, is glocalization our sustainability future? Sustain. Sci. Pract. Pol. 16 (1), 48-52.

Gray, R.S., (2020). Agriculture, transportation, and the COVID-19 crisis. Canadian Journal of Agricultural Economics/Revue Canadienne d'agroeconomie 68 (2), 239-243.

Gundy, P.M., Gerba, C.P., Pepper, I.L.,(2008). Survival of coronaviruses in water and wastewater. Food and Environmental Virology 1 (1), 10.

Gupta, A., Bherwani, H., Gautam, S., Anjum, S., Musugu, K., Kumar, N., Anshul, A., Kumar, R., (2020). Air pollution aggravating COVID-19 lethality? Exploration in Asian cities using statistical models. Environ. Dev. Sustain. https://doi.org/10.1007/ s10668-020-00878-9.

Hair, J.F; Anderson, R.E; Thatam, R.L; \& Black, W.C. (2014). Multivariate Data Analysis With Reading, 7th Edition. Englewood Cliffs, NJ: Prentice Hall.

Hasibuan,S.P.Malayu.(2008). Manajemen Sumber Daya Manusia. (edisi revisi), Jakarta : Bumi Aksara.

Haryanto (2010), Manajemen Administrasi Rumah Sakit. Penerbit : Jakarta Edisi Ke dua.

Henriques, M., (2020). Will COVID-19 Have a Lasting Impact on the Environment? BBC. March 27th. Retrieved from. https://www.bbc.com/future/article/20200326-COVI D-19-theimpact-of-coronavirus-on-the-environment.

Hertati. L (2015). Competence of Human Resources, The Benefits of Information Technology on Value of Financial Reporting in Indonesia. Research Journal of Finance and Accounting 6, (8) $12-18$

Hertati.L. Zarkasyi.W.Suharman.H.Umar.H.(2019). The Effect of Human Resource Ethics on Financial Reporting Implications for Good Government Governance (Survey of Related Sub-units in State-owned Enterprises in SUMSEL). International Journal of Economics and Financial. 9(4), 267-276

Hertati.L , Zarkasy.W, Adam.M., Umar.H, Suharman.H.(2020). Decrease in Labor Levels in the Covid-19 Government Budget. Ilomata International Journal of Tax \& Accounting. 1 (4) .193-209

Hertati.L, Syafarudin.A, Safkaur.O. Fery.I. 2020. Peran Manajemen Perubahan Pada Akuntansi Manajemen Strategis Akibat Virus Corona . Jurnal Revenue : Jurnal Ilmiah Akuntansi 1 (2). 201-216.

Husein (2007).Fakta Penelitian. Jakarta :Penerbit PT. Grafindo Persada

Hossain, M., 2020. Current Status of Global Research on Novel Coronavirus Disease (COVID-19): A Bibliometric Analysis and Knowledge Mapping. SSRN. https://doi. org/10.2139/ssrn.3547824. April 2nd. Retrieved from.

Howarth, C., Bryant, P., Corner, A., Fankhauser, S., Gouldson, A., Whitmarsh, L., Willis, R., (2020). Building a social mandate for climate action: lessons from COVID- 19. Environ. Resour. Econ. 76 (4), 1107-1115. https://doi.org/10.1007/s10640- 020-00446-9.

Iqbal, N., Fareed, Z., Shahzad, F., He, X., Shahzad, U., Lina, M., (2020). The nexus between COVID19 , temperature and exchange rate in Wuhan city: new findings from partial and multiple wavelet coherence. Sci. Total Environ. 729, 138916. https://doi.org/ 10.1016/j.scitotenv.2020.138916.

Inversini, A., Boes, K., Buhalis, D., (2016). Smart tourism destinations: ecosystems for tourism destination competitiveness. International Journal of Tourism Cities 2 (2), 108-124.

Jribi, S., Ben Ismail, H., Doggui, D., Debbabi, H., (2020). COVID-19 virus outbreak lockdown: what impacts on household food wastage? Environ. Dev. Sustain. 22 (5), 3939-3955.

Volume 2 Issue 2 (2021)

Economics and Digital Business Review

ISSN: 2774-2563 (Online) 
Lesi Hertati ${ }^{凶}$, Rilla Gantino², Lilis Puspitawati³, Meifida Ilyas ${ }^{4}$, Otniel Safkaur5.

Jumba, F.R., Tibasiima, T., Byaruhanga, E., Aijuka, J., Pabst, H., Nakalanda, J.M., Kabaseke, C., (2020). Covid 19: lets act now: the urgent need for upscaling agroecology in Uganda (2020). Int. J. Agric. Sustain. 1-7.

Karuppasamy, M.B., Seshachalam, S., Natesan, U., Ayyamperumal, R., Karuppannan, S., Gopalakrishnan, G., Nazir, N., (2020). Air pollution improvement and mortality rate

Keulertz, M., Mulligan, M., Allan, J.A., (2020). The impact of COVID-19 on water and food systems: flattening the much bigger curve ahead. Water Int. 45 (5), 430-434.

Kleinschroth, F., Kowarik, I., (2020). COVID-19 crisis demonstrates the urgent need for urban greenspaces. Front. Ecol. Environ. 18 (6), 318-319.

Klenert, D., Funke, F., Mattauch, L., O'Callaghan, B., (2020). Five lessons from COVID-19 for advancing climate change mitigation. Environ. Resour. Econ. 76 (4), 751-778

La Rosa, G., Iaconelli, M., Mancini, P., Bonanno Ferraro, G., Veneri, C., Bonadonna, L., Lucentini, L., Suffredini, E., (2020). First detection of SARS-CoV-2 in untreated wastewaters in Italy.

Lawley, C., (2020). Potential impacts of COVID-19 on Canadian farmland markets. Canadian Journal of Agricultural Economics/Revue Canadienne d'agroeconomie 68 (2), 245-250.

Li, X., Song, Y., Wong, G., Cui, J., (2020). Bat origin of a new human coronavirus: there and back again. Science China. Life Sci. 63 (3), 461-462.

Lin, J., Huang, W., Wen, M., Li, D., Ma, S., Hua, J., Zhang, Q., (2020). Containing the spread of coronavirus disease 2019 (COVID-19): meteorological factors and control strategies.

Lindsey, P., Allan, J., Brehony, P., Dickman, A., Robson, A., Begg, C., Bhammar, H., Blanken, L., Breuer, T., Fitzgerald, K., Flyman, M., Gandiwa, P., Giva, N., Kaelo, D., Nampindo, S., Nyambe, N., Steiner, K., Parker, A., Roe, D., et al., (2020). Conserving Africa's wildlife and wildlands through the COVID-19 crisis and beyond. Nat. Ecol. Evol.

Manullang, M. (2008). Dasar-dasar Manajemen. Yogyakarta : Gadja Mada.

Martoyo. (2008). Manajemen Sumber daya Manusia. (edisi ketiga), Jakarta : PT. Rineka Cipta.

Ma, Yueling, et al., 2020. Effects of temperature variation and humidity on the death of COVID-19 in Wuhan, China. Sci. Total Environ. 724, 138226.

Ma, C.-J., Kang, G.-U., (2020). Air quality variation in wuhan, daegu, and tokyo during the explosive outbreak of COVID-19 and its health effects. Int. J. Environ. Res. Publ. Health 17 (11).

Meles, T.H., Ryan, L., Wheatley, J., (2020). COVID-19 and EU climate targets: can we now go further? Environ. Resour. Econ. 1-9.

Mlejnkova, H., Sovova, K., Vasickova, P., Ocenaskova, V., Jasikova, L., Juranova, E., (2020). Preliminary study of sars-cov-2 occurrence in wastewater in the Czech republic. Int. J. Environ. Res. Publ. Health 17 (15),

Morawska, L., Cao, J., (2020). Airborne transmission of SARS-CoV-2: the world should face the reality. Environ. Int. 139,

Mukanjari, S., Sterner, T., (2020). Charting a "green path" for recovery from COVID-19. Environ. Resour. Econ. 76 (4), 825-853.

Negara, (2008). Ketetapan Pengawasan.Penerbit : Struktur Organisasi Sekayu : RSUD.

Negara, (2001). Organisasi Pengawasan. Penerbit: Jakarta Bina Aksara.

Notoatmojo (2009).Pengembangan Sumber Daya Manusia. (edisi ketiga), Jakarta : PT. Rineka Cipta.

Nadikattu, R.R., Mohammad, S.M., Whig, P., 2020. Novel economical social distancing smart Device for COVID-19 (SSRN Scholarly Paper ID 3640230). In: Social Science Research Network.

Nabi, G., Siddique, R., Ali, A., Khan, S., (2020). Preventing bat-born viral outbreaks in future using ecological interventions. Environ. Res. 185,

Pirouz, B., Shaffiee, H., Sina, S., Sami, Piro, P., (2020). Investigating a serious challenge in the sustainable development process: analysis of confirmed cases of COVID-19 (new type of

Volume 2 Issue 2 (2021)

Economics and Digital Business Review

ISSN: 2774-2563 (Online) 
Lesi Hertati ${ }^{\bowtie}$, Rilla Gantino ${ }^{2}$, Lilis Puspitawati³, Meifida Ilyas 4 , Otniel Safkaur5.

coronavirus) through a binary classification using artificial intelligence and regression analysis. Sustainability 12 (6), 2427.

Prata, D.N., Rodrigues, W., Bermejo, P.H., (2020). Temperature significantly changes COVID-19 transmission in (sub)tropical cities of Brazil. Sci. Total Environ. 729, 138862.

Radanliev, P., Roure, D.C.D., Walton, R., (2020). Data mining and analysis of scientific research data records on COVID-19 mortality, immunity, and vaccine development-in the first wave of the COVID-19 pandemic (SSRN Scholarly Paper ID

Siagian (2008), Fungsi-fungsi Manajerial. Jakarta : Bina Aksara.

Syaparudin.A \& Hertati.L.(2020). Penerapan Human Capital, Kualitas Pelayanan Pada Sistem Informasi Manajemen. @is The Best: Accounting Information Systems and Information Technology Business Enterprise Volume 5, Nomor 1 (2020) Hal. 31-45. 